\title{
Evaluation of hysterectomy in a tertiary care hospital of central India: a retroprospective study
}

\author{
Anchala Mahilange* \\ Department of Obstetrics and gynaecology, DBRAMH, Pt JNM medical college, Raipur, Chhattisgarh, India
}

Received: 27 August 2021

Accepted: 08 September 2021

\section{*Correspondence:}

Dr. Anchala Mahilange,

E-mail: amahilange@gmail.com

Copyright: $\odot$ the author(s), publisher and licensee Medip Academy. This is an open-access article distributed under the terms of the Creative Commons Attribution Non-Commercial License, which permits unrestricted non-commercial use, distribution, and reproduction in any medium, provided the original work is properly cited.

\begin{abstract}
Background: Hysterectomy is the most common gynaecological surgical procedure after caesarean section. In India there is lower rate (4-6\%) of hysterectomy has been reported, while there is higher frequency of hysterectomy (10-20\%) in developed countries. Currently there are three main types of hysterectomy operations in practice for benign diseases abdominal hysterectomy, vaginal hysterectomy and laparoscopic hysterectomy. Abdominal hysterectomy remains the predominant method of uterus removal. The present study was planned t to analyse changes in the trends of hysterectomy from past 3 year in the study area.

Methods: The present observational study was conducted in department of obstetrics and gynaecology and associated Dr. B.R.A.M. hospital Raipur (CG), India. Data was collected retrospectively from January 2009 to May 2012 from hospital medical records. Prospectively data was obtained from patient and his file from June 2013 to September 2014. Data was compiled in MS-excel and checked for its completeness and correctness, and then it was analyzed by using suitable software.

Results: Total no of hysterectomy conducted in study duration was 1000. Study showed declining trend of hysterectomy in our institute. Most common age group of hysterectomy was 41-50 year. which $45.8 \%$ followed by age group 31-40 that is $32.5 \%$. Most common indication of hysterectomy was fibroid uterus $33.6 \%$ followed by prolapse uterus $29.5 \%$. $29 \%$ cases were operated via vaginal route for descent of uterus and $21 \%$ cases operated by vaginal route for nondescent uterus. $50 \%$ cases were operated via abdominal route. Average operating time for TAH was $1.43 \pm 0.50$, for VH was $1.08 \pm 0.03$. Average hospital stay for TAH was $8.87 \pm 3.31$ and $\mathrm{VH}$ was $5.27 \pm 1.07$.

Conclusions: In our study it had been seen that rate of hysterectomy is in decreasing trend as more conservative approach is now preferred. To minimize most of complications of hysterectomy second opinion fresh eyes and multidisciplinary approach is recommend in all patients undergoing this procedure.
\end{abstract}

Keywords: Hysterectomy, Fibroid uterus, Adenomyosis, Leiomyoma

\section{INTRODUCTION}

Hysterectomy is the most common gynaecological surgical procedure after caesarean section. In India there is lower rate (4-6\%) of hysterectomy has been reported, while there is higher frequency of hysterectomy (10-20\%) in developed countries. ${ }^{1}$ Over 600,000 hysterectomies were having been performed in US alone in 2003 according to reports, out of them $90 \%$ were performed for benign conditions. ${ }^{2}$

According to international data base 2014 2.16/1000 women have had hysterectomy. ${ }^{3}$ Age specific prevalence of hysterectomy in 2008 of $15.1 \%$ in women aged $45-55$ year. ${ }^{4}$ 
Currently there are three main types of hysterectomy operations in practice for benign diseases abdominal hysterectomy, vaginal hysterectomy and laparoscopic hysterectomy. Abdominal hysterectomy remains the predominant method of uterus removal.

The common indications of hysterectomy are fibroid uterus, dysfunctional uterine bleeding(DUB), prolapsed genital organ, Leiomyoma, endometriosis, pelvic inflammatory disease, endometrial hyperplasia, menorrhagia, dysmenorrhoea or pelvic pain associated with significant pelvic disease, intractable postpartum haemorrhage, endometrial hyperplasia with atypia and malignancies such as cervical intraepithelial neoplasia or invasive Disease etc. using a variety of techniques and approaches including abdominal, vaginal. In India, most of the surgeons prefer vaginal hysterectomy. ${ }^{4}$

Overall mortality rates for $\mathrm{AH}$ or $\mathrm{VH}$ are $0.1-0.2 \%$. Morbidity rates have been estimated at $6.1 \%$. One of the most reported adverse effects of hysterectomy are lower urinary tract symptoms particularly urinary incontinence. The most serious postoperative complication is haemorrhage $(0.2-2 \%)$ About $10 \%$ patients are expected to have postoperative febrile morbidity and infection. The bladder may be injured in $2.9 \%$ of all hysterectomies. Ureteral injury occurs in $0.7-1.8 \%$ of $\mathrm{AH}$ and $0.1 \%$ of VH. ${ }^{5}$

The present study makes an attempt to analyze changes in the trends of hysterectomy from past 3 year in the hospital. There is lack of studies in India regarding age, incidence, and indications of hysterectomy so we want to make a study to highlight this field.

\section{Aims and objectives}

To observe the trends of hysterectomy in the study area. To study the age, indications, route of hysterectomy, histopathology and postoperative complication.

\section{METHODS}

The present observational study was conducted in department of obstetrics and gynecology and associated Dr. B.R.A.M. hospital Raipur (CG). It was retrospective and prospective observational study conducted in women with hysterectomy in period from January 2009 to September 2014.

\section{Inclusion criteria}

All the women of any age who underwent hysterectomy from January 2009 to September 2014 were included in the study.

\section{Exclusion criteria}

Exclusion criteria for the study was emergency obstetric hysterectomy.
The study was conducted retrospectively and prospectively in women fulfilling inclusion criteria. The data was collected retrospectively from January 2009 to May 2012 from hospital medical records. Prospectively data was obtained from patient and his file from June 2013 to September 2014. Information was gathered regarding age, parity clinical features (presenting illness), menstrual history and preoperative diagnosis /indication of hysterectomy. Outcome was measured in terms of operative time in minutes, bladder ureteric injury and primary hemorrhage. Postoperative outcome was measured in terms of wound infection UTI, hospital stay, pyrexia, secondary hemorrhage, readmission, reopening and mortality. Histopathology reports of same patient were collected from department of pathology and their diagnosis was noted. Data was compiled in ms-excel and checked for its completeness and correctness, and then it was analyzed by using suitable software. $\mathrm{P}$ value $<0.05$ was considered as statistically significant.

\section{RESULTS}

Total no of hysterectomy conducted in study duration was 1000. In the year 2009 total no of hysterectomy conducted was 194, in 2010 it was 207, in 2011 it was 179, in 2012 it was 150, in 2013 it was 165 and in 2014 up to September it was 105 . The rate of hysterectomy was $14.9 \%, 15.8 \%$, $13.07 \%, 10.7 \%, 11.45 \%, 9.61 \%$, respectively in year 2009 , 2010, 2011, 2012, 2013 and 2014. This shows declining trend of hysterectomy in our institute (Table 1).

Table 1: Estimated number and rate of hysterectomy.

\begin{tabular}{|llll|}
\hline $\begin{array}{l}\text { S. } \\
\text { no. }\end{array}$ & Year & No. & Rate $/ \mathbf{1 0 0 0}$ \\
\hline 1. & 2009 & 194 & 14.9 \\
\hline 2. & 2010 & 207 & 15.8 \\
\hline 3. & 2011 & 179 & 13.07 \\
\hline 4. & 2012 & 150 & 10.72 \\
\hline 5. & 2013 & 165 & 11.45 \\
\hline 6. & 2014 (up to September) & 105 & 9.61 \\
\hline
\end{tabular}

Total no of hysterectomy conducted in study duration was 1000. In the year 2009 total no of hysterectomy conducted was 194, in 2010 it was 207, in 2011 it was 179, in 2012 it was 150 , in 2013 it was 165 and in 2014 up to September it was 105 . The rate of hysterectomy was $14.9 \%, 15.8 \%$, $13.07 \%, 10.7 \%, 11.45 \%, 9.61 \%$, respectively in year 2009 , 2010, 2011, 2012, 2013 and 2014. This shows declining trend of hysterectomy in our institute (Table 1).

$29 \%$ cases were operated via vaginal route for descent of uterus and $21 \%$ cases operated by vaginal route for nondescent uterus.50\% cases were operated via abdominal route (Table 2 ).

Average operating time for TAH was $1.43 \pm 0.50$, for $\mathrm{VH}$ was 1.08 \pm 0.03 . Average hospital stay for $\mathrm{TAH}$ was $8.87 \pm 3.31$ and $\mathrm{VH}$ was $5.27 \pm 1.07$ (Table 3 ). 


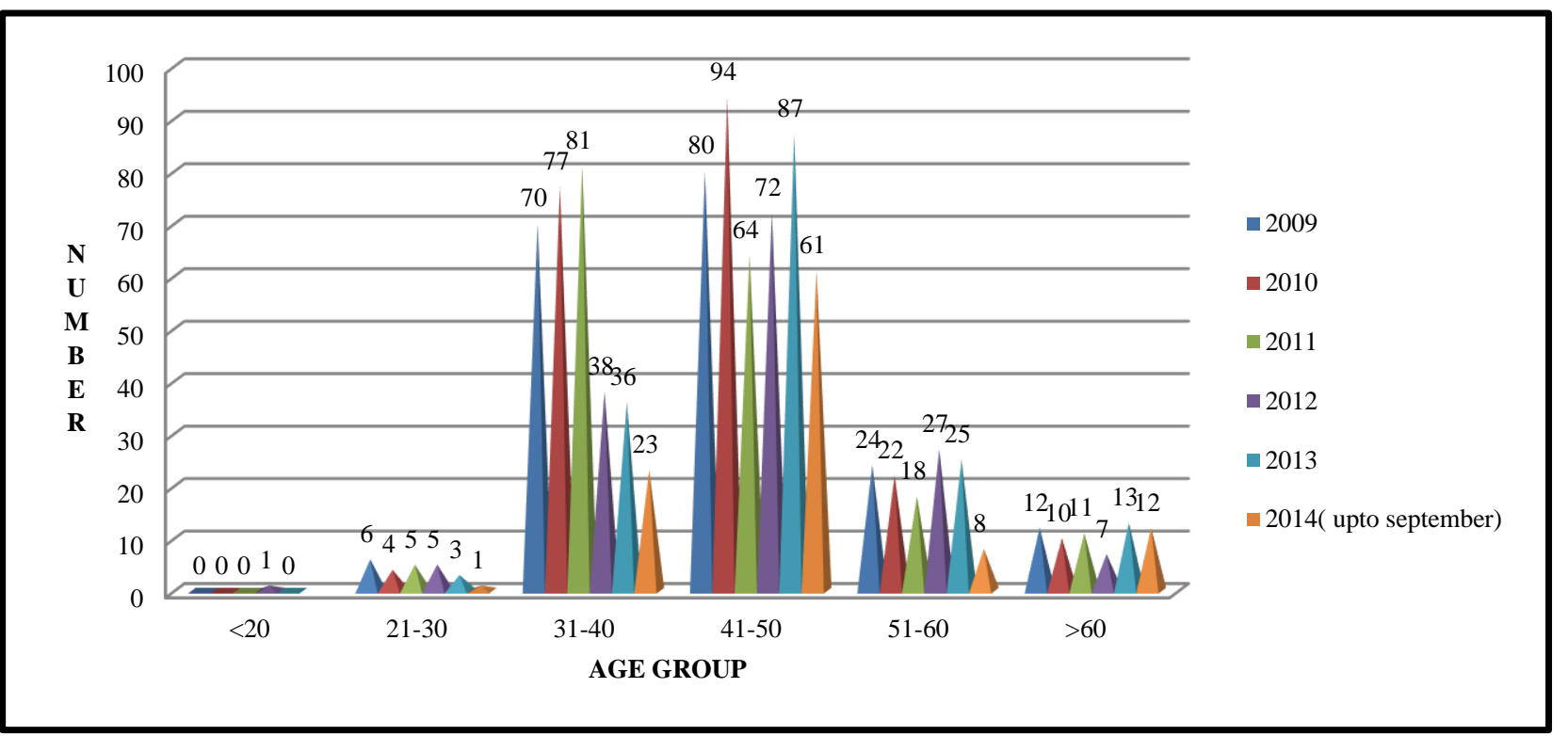

Figure 1: Age wise distribution of hysterectomy.

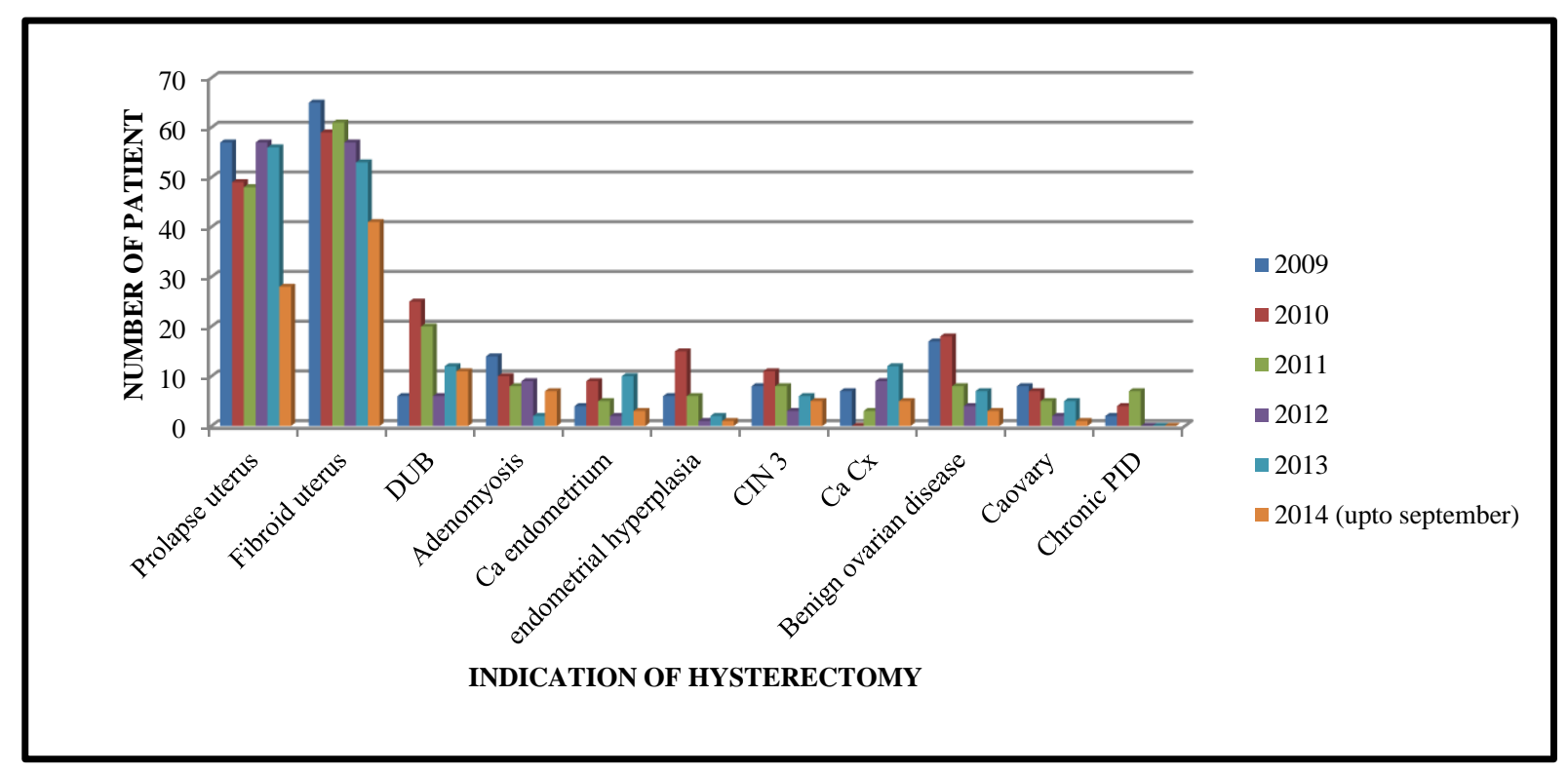

Figure 2: Distribution according to indication.

Table 2: Distribution according to type of hysterectomy.

\begin{tabular}{|c|c|c|c|c|c|c|c|c|c|c|c|c|}
\hline \multirow{2}{*}{ Type } & \multicolumn{2}{|c|}{2009} & \multicolumn{2}{|c|}{2010} & \multicolumn{2}{|c|}{2011} & \multicolumn{2}{|c|}{2012} & \multicolumn{2}{|c|}{2013} & \multicolumn{2}{|c|}{2014 (up to Sep.) } \\
\hline & $\mathbf{N}$ & $\%$ & $\mathbf{N}$ & $\%$ & $\mathbf{N}$ & $\%$ & $\mathbf{N}$ & $\%$ & $\mathbf{N}$ & $\%$ & $\mathbf{N}$ & $\%$ \\
\hline VH & 56 & 28.86 & 49 & 23.67 & 44 & 26.03 & 56 & 35 & 55 & 33.33 & 28 & 27.35 \\
\hline NDVH & 47 & 24.22 & 59 & 28.5 & 44 & 24.58 & 27 & 18 & 17 & 10.30 & 13 & 12.26 \\
\hline ТАН & 24 & 12.37 & 40 & 19.32 & 45 & 25.13 & 34 & 22.66 & 54 & 32.72 & 51 & 48.11 \\
\hline $\begin{array}{l}\text { TAH } \\
\text { with LSO }\end{array}$ & 2 & 1.03 & 1 & 0.48 & 5 & 6.50 & 8 & 5 & 2 & 1.21 & 2 & 1.88 \\
\hline $\begin{array}{l}\text { TAH } \\
\text { with RSO }\end{array}$ & 4 & 2.06 & 1 & 0.48 & 8 & 0.59 & 4 & 2.5 & 3 & 1.81 & 0 & 0 \\
\hline $\begin{array}{l}\text { TAH } \\
\text { with BSO }\end{array}$ & 61 & 31.44 & 57 & 27.53 & 33 & 19.52 & 21 & 13.12 & 34 & 20.60 & 11 & 10.37 \\
\hline Total & 194 & & 207 & & 179 & & 150 & & 165 & & 105 & \\
\hline
\end{tabular}


Table 3: Surgical results.

\begin{tabular}{|c|c|c|c|c|c|c|c|c|c|c|c|c|c|c|c|}
\hline \multirow[b]{2}{*}{ Parameters } & \multicolumn{5}{|c|}{ TAH } & \multicolumn{9}{|c|}{ VH } & \multirow[b]{2}{*}{ P value } \\
\hline & 2009 & 2010 & 2011 & 2012 & 2013 & $\begin{array}{l}2014 \\
\text { (upto Sep) }\end{array}$ & Total & 2009 & 2010 & 2011 & 2012 & 2013 & $\begin{array}{l}2014 \\
\text { (upto Sep) }\end{array}$ & Total & \\
\hline $\begin{array}{l}\text { Average } \\
\text { operating } \\
\text { time } \\
\text { (hours) }\end{array}$ & $\begin{array}{l}1.07 \pm \\
0.23\end{array}$ & $\begin{array}{l}1.04 \pm \\
0.16\end{array}$ & $\begin{array}{l}1.297 \pm \\
0.36\end{array}$ & $\begin{array}{l}1.287 \pm \\
0.32\end{array}$ & $\begin{array}{l}1.438 \pm 0 \\
.50\end{array}$ & $\begin{array}{l}9.7 \pm \\
5.25\end{array}$ & $\begin{array}{l}8.59 \pm \\
2.5\end{array}$ & $\begin{array}{l}1.077 \pm \\
0.16\end{array}$ & $\begin{array}{l}1.0 \pm \\
0.16\end{array}$ & $\begin{array}{l}0.936 \pm \\
0.23\end{array}$ & $\begin{array}{l}1.031 \pm \\
0.19\end{array}$ & $\begin{array}{l}1.0 \pm \\
0.33\end{array}$ & $\begin{array}{l}5.34 \pm \\
0.79\end{array}$ & $\begin{array}{l}5.08 \pm \\
0.96\end{array}$ & 0.001 \\
\hline $\begin{array}{l}\text { Average } \\
\text { hospital } \\
\text { stay (days) }\end{array}$ & $\begin{array}{l}8.6 \pm \\
1.95\end{array}$ & $\begin{array}{l}8.2 \pm \\
1.25\end{array}$ & $\begin{array}{l}8.3 \pm \\
1.87\end{array}$ & $\begin{array}{l}8.8 \pm \\
3.49\end{array}$ & $\begin{array}{l}8.8 \pm \\
3.31\end{array}$ & $\begin{array}{l}1.51 \pm \\
0.53\end{array}$ & $\begin{array}{l}1.21 \pm \\
0.37\end{array}$ & $\begin{array}{l}4.8 \pm \\
0.47\end{array}$ & $\begin{array}{l}4.8 \pm \\
0.63\end{array}$ & $\begin{array}{l}5.2 \pm \\
1.51\end{array}$ & $\begin{array}{l}5.3 \pm \\
0.84\end{array}$ & $\begin{array}{l}5.2 \pm \\
1.07\end{array}$ & $\begin{array}{l}1.18 \pm \\
0.45\end{array}$ & $\begin{array}{l}1.1 \pm \\
0.33\end{array}$ & 0.0001 \\
\hline
\end{tabular}

Table 4: Histopathological lesion of hysterectomy specimen.

\begin{tabular}{|c|c|c|c|c|c|c|c|c|c|c|c|c|c|c|}
\hline \multirow[t]{2}{*}{ Histopathological diagnosis } & \multirow[b]{2}{*}{$\mathbf{N}$} & \multirow[b]{2}{*}{$\%$} & \multicolumn{2}{|c|}{2010} & \multicolumn{2}{|c|}{2011} & \multicolumn{2}{|c|}{2012} & \multicolumn{2}{|c|}{2013} & \multicolumn{2}{|c|}{$\begin{array}{l}2014 \\
\text { (up to Sep) }\end{array}$} & \multicolumn{2}{|c|}{ Total } \\
\hline & & & $\mathbf{N}$ & $\%$ & $\mathbf{N}$ & $\%$ & $\mathbf{N}$ & $\%$ & $\mathbf{N}$ & $\%$ & $\mathbf{N}$ & $\%$ & $\mathbf{N}$ & $\%$ \\
\hline Leiomyoma & 64 & 32.47 & 58 & 28.01 & 56 & 31.36 & 52 & 34.37 & 49 & 29.69 & 38 & 36.19 & 317 & 31.7 \\
\hline Adenomyosis & 20 & 8.76 & 36 & 17.39 & 19 & 9.46 & 12 & 9.37 & 19 & 11.51 & 16 & 15.23 & 122 & 12.2 \\
\hline Chronic cervicitis & 60 & 30.92 & 49 & 23.67 & 78 & 42.01 & 41 & 29.37 & 43 & 26.06 & 25 & 23.80 & 296 & 29.6 \\
\hline CIN 1,2 and 3 & 11 & 4.63 & 19 & 8.69 & 14 & 7.10 & 23 & 15.62 & 21 & 19.39 & 9 & 8.57 & 97 & 9.7 \\
\hline CA cervix & 13 & 6.70 & 0 & 0 & 4 & 2.36 & 6 & 3.75 & 15 & 9.09 & 4 & 3.80 & 42 & 4.2 \\
\hline CA endometrium & 4 & 2.06 & 8 & 1.44 & 2 & 1.18 & 3 & 1.87 & 10 & 5.45 & 4 & 3.80 & 31 & 3.1 \\
\hline Atropic endometrium & 16 & 8.24 & 13 & 6.28 & 16 & 8.87 & 10 & 6.87 & 12 & 7.5 & 1 & 0.95 & 68 & 6.8 \\
\hline Endometrial Hyperplasia & 5 & 2.57 & 16 & 7.72 & 12 & 7.10 & 2 & 1.25 & 1 & 2.42 & 2 & 1.90 & 38 & 3.8 \\
\hline Endometrial proliferative phase & 36 & 18.5 & 40 & 20.6 & 34 & 20.11 & 32 & 20 & 29 & 18.12 & 12 & 11.42 & 183 & 18.3 \\
\hline $\begin{array}{l}\text { Combined leiomyoma and } \\
\text { adenomyosis }\end{array}$ & 2 & 1.03 & 2 & 0.9 & 3 & 1.18 & 2 & 1.25 & 1 & 1.21 & 2 & 1.90 & 12 & 1.2 \\
\hline Ovarian carcinoma & 10 & 5.15 & 7 & 3.38 & 4 & 2.36 & 2 & 1.25 & 5 & 2.42 & 3 & & 31 & 2.9 \\
\hline Benign ovarian disease & 15 & 5.67 & 19 & 9.66 & 5 & 2.95 & 2 & 1.25 & 7 & 4.24 & 3 & 2.85 & 51 & 5.1 \\
\hline
\end{tabular}

Table 5: Immediate post-operative complication.

\begin{tabular}{|c|c|c|c|c|c|c|c|}
\hline Immediate post op complications & No of TAH $(n=505)$ & $\%$ of TAH & No of VH $(n=495)$ & $\%$ of $\mathrm{VH}$ & Total & $P$ value & Significance \\
\hline Wound infection & 26 & $9.7 \%$ & 0 & 0 & 26 & 0.009 & Significant \\
\hline Pt. needed post op blood transfusion & 32 & 28.11 & 9 & 10.7 & 41 & 0.0001 & Significant \\
\hline Unexplained fever & 35 & 10.8 & 10 & 6.26 & 45 & 0.0001 & Significant \\
\hline Paralytic ileus & 5 & 1.98 & 1 & 0.2 & 6 & 0.0001 & Significant \\
\hline
\end{tabular}


Table 6: Intermediate complications.

\begin{tabular}{|llllllll|}
\hline $\begin{array}{l}\text { Intermediate } \\
\text { complications }\end{array}$ & TAH & $\%$ & VH & $\%$ & Total & P value & Significance \\
\hline UTI & 6 & 2.3 & 10 & 3.03 & 16 & 0.0001 & Significant \\
\hline Vault prolapse & 0 & 0 & 1 & 0.2 & 1 & 0.055 & $\begin{array}{l}\text { Not } \\
\text { significant }\end{array}$ \\
\hline $\begin{array}{l}\text { Uretrovaginal } \\
\text { fistula }\end{array}$ & 2 & 0.39 & 0 & 0 & 2 & 0.455 & $\begin{array}{l}\text { Not } \\
\text { significant }\end{array}$ \\
\hline $\begin{array}{l}\text { Require } \\
\text { resuturing }\end{array}$ & 5 & 4.5 & 0 & 0 & 5 & 0.233 & $\begin{array}{l}\text { Not } \\
\text { significant }\end{array}$ \\
\hline Psychosis & 2 & 0.39 & 0 & 0 & 2 & 0.455 & $\begin{array}{l}\text { Not } \\
\text { significant }\end{array}$ \\
\hline $\begin{array}{l}\text { Retention of } \\
\text { urine }\end{array}$ & 2 & 1.3 & 0 & 0 & 2 & 0.455 & $\begin{array}{l}\text { Not } \\
\text { significant }\end{array}$ \\
\hline $\begin{array}{l}\text { Vaginal } \\
\text { haemorrhage }\end{array}$ & 1 & 2.3 & 2 & 0.4 & 3 & 0.055 & $\begin{array}{l}\text { Not } \\
\text { significant }\end{array}$ \\
\hline Pelvic infection & 2 & 0.39 & 0 & 0 & 2 & 0.455 & $\begin{array}{l}\text { Not } \\
\text { significant }\end{array}$ \\
\hline Total & 118 & $23.36 \%$ & 33 & $6.66 \%$ & 77 & 0.0001 & significant \\
\hline
\end{tabular}

Most common histopathology found was leiomyoma $39.7 \%$ followed by chronic cervicitis $21.6 \%$. 91.3\% preoperative diagnosis was confirmed by histopathology. Leiomyoma which is most common histopathology found, was correlated clinically with $92.6 \%$ cases of preoperative diagnosis of fibroid, rest of cases were found $4.6 \%$ cases of adenomyosis, $1.5 \%$ cases of endometrial hyperplasia and $1.2 \%$ cases of CIN 1. Chronic cervicitis was found in prolapse uterus mostly as histopathological diagnosis (Table 4).

Complication of TAH wound infection $9.7 \%$ in TAH, no of patient needed blood transfusion $28.11 \%$, unexplained fever $10.8 \%$, paralytic ileus $1.98 \%$ require resuturing 4.5 $\%$, psychosis $0.39 \%$, ureterovaginal fistula $1.39 \%$, post op haemorrhage $1.39 \%$. In case of $\mathrm{VH}$ major complication was patient needed blood transfusion $10.7 \%$, unexplained fever in $6.26 \%$, vault prolapse $0.2 \%$, UTI $3.03 \%$ (Table 5 and 6).

\section{DISCUSSION}

In our study, the rate of hysterectomy shows the decreasing trend from 2009 to 2014, while in other studies no significant changes in annual incidence of hysterectomy. ${ }^{6}$ In 2009 the rate of hysterectomy was 14.9/1000 women and 2014 it is 9.61/1000 women. There is negative correlation in year and rate of hysterectomy ( $\mathrm{R}$ value is 0.927 ) and $p$ value of trend is -0.008 . It clearly indicates more conservative approach.

In our study most common age group was 41-50 years which is same as other studies. ${ }^{7,8}$ One of our patients was under the age of 20 years and the hysterectomy was performed due to a large lump over abdomen and her histopathology report was rhabdomyosarcoma.
Our study shows that most common indication of hysterectomy was fibroid uterus $(33.6 \%)$ which is in agreement with other reports in literature. ${ }^{3,4}$ While in others most common indication is menorrhagia followed by fibroid uterus and in others prolapse uterus was the most common indication and in others dub followed by fibroid. ${ }^{8-10}$

2nd most common indication was prolapse uterus (29.4\%). Other indication followed by that was adenomyosis $(5 \%)$ and $(8 \%)$ DUB.

The usual ratio of vaginal hysterectomy to abdominal hysterectomy is 1:4. ${ }^{11}$ Abdominal hysterectomy allows better visualization of the abdominal cavity during surgery. Most of TAH was performed for fibroid uterus of $33.6 \%$ cases while most of $\mathrm{VH}$ performed for prolapse uterus for $29.4 \%$ cases. $6(0.6 \%)$ cases of first degree cervical descent operated by abdominal route because there was coexisting other pathology fibroid uterus, ovarian cyst.

The incidence of NDVH was $21 \%$ in our study period. In our setup most common indication of NDVH was fibroid uterus 35\% followed by DUB27\% same as others, whereas in other studies 12 most common indication was DUB followed by fibroid uterus. ${ }^{11,12}$

Leiomyoma $(31.7 \%)$ was the most common histopathology found.7 Adenomyosis was found in $4.6 \%$, whereas endometrial hyperplasia in $1.5 \%$ and CIN in $1.3 \%$. In most of the cases of prolapse uterus we found chronic cervicitis $(29.6 \%)$ in histopathology report which is 2 nd most common histopathology in our study.

Other histopathological diagnosis was adenomyosis $12.2 \%$. Ca Cervix found in $4.2 \%$ histopathology report. 
Histopathological examination of surgical specimen carries ethical, legal, diagnostic and therapeutic significance. So, it is very important to send all specimens for histopathological examination for confirmation of diagnosis and further management.

In our study mean duration of operation and average hospital stay for TAH is more than $\mathrm{VH} p$ value 0.001 which is similar to other studies. ${ }^{13}$ While in contrast study done by Pradhanang et al shorter hospital stays for TAH group than VH group. Shorter hospital stay is a desirable outcome for both patient and hospital. ${ }^{12}$

In our data analysis, the complication rate was $15.3 \%$ which is similar to other studies. ${ }^{13}$ Complications were significantly more common with abdominal hysterectomy (23\%) than $\mathrm{VH}(6.6 \%)$, which is comparable to a large multicentric retrospective study conducted by US Centre for Disease Control over the period of four years, in which the overall complication rate was $20.5 \%$ for vaginal hysterectomy compared $42.8 \%$ for abdominal hysterectomy and it is comparable to other studies also. ${ }^{12}$ Most common complication is hemorrhage same as other studies. $^{12}$

There is no wound infection in $\mathrm{VH}$ while in case of TAH wound infection in cases of $9.7 \%(\mathrm{p}=0.0001)$ and about $1 \%$ cases require wound resuturing. Patient needed post operatively blood transfusion in $28.1 \%$ in TAH and $10.7 \%$ in VH $(\mathrm{p}=0.0001)$. Patients had unexplained fever in $10.2 \%$ cases in TAH and $6.2 \%$ cases in $\mathrm{VH}$, in contrast to study done by others. ${ }^{13} \quad(p=0.0001)$ Infections can be reduced by lessening the spill of vaginal bacteria into operative site and vaginal douche by iodine before surgery and routine use of antibiotics.

UTI is more in cases of VH $3 \%$ and $2.3 \%$ in TAH $(p=0.001)$. Retention of urine was seen in $1.3 \%$ cases of TAH and $0.39 \%$ cases had seen with psychosis.

There are $0.2 \%$ cases of ureteric injury reported in case of TAH during study period and other visceral injuries were not reported, whereas injuries to bladder and intestine have been reported in other studies. ${ }^{13}$ Before taking decision for hysterectomy, always medical/ minimal invasive management must be done.

\section{CONCLUSION}

Although so many options of medical treatments and conservative surgeries are available, but hysterectomy is still commonly performed procedure even in developed countries. In our study it had been seen that rate of hysterectomy is in decreasing trend as more conservative approach is now preferred. In our study rate of vaginal and abdominal hysterectomy is almost equal as rate of NDVH is high in our institute. To minimize most of complications of hysterectomy second opinion fresh eyes and multidisciplinary approach is recommend in all patients undergoing this procedure. Regular careful audit can help in improving the quality of health care services in our country and providing safe and cost-effective management options.

\section{Funding: No funding sources}

Conflict of interest: None declared

Ethical approval: The study was approved by the Institutional Ethics Committee

\section{REFERENCES}

1. Amarjeet $\mathrm{S}$, Arvinderkaur A. Why hysterectomy rate are lower in India. IJCM. 2016;75(101):163-31.

2. Lan Z, Jing-he L, Chun-yan L, Hong-hui S, Zhi-jing S, Rong F.Clinical assessment for three routes of hysterectomy. Chin Med J. 2009;122(4):377-80.

3. Singh S. Hysterectomy trends in rural India- an analytic study. Int $\mathbf{J}$ Clin Obst Gynaecol. 2019;3(3):166-8.

4. Bala KR, Devi P, Singh CM. Trends of hysterectomy: a retrospective analysis in RIMS, Imphal. Jmedsoc. 2021;29:121-4.

5. Yakasai IA. Complications of Hysterectomy: A Review. Brit J Sci. 2013;9(2):120-3.

6. Sobande AA, Eskander M, Archibong EI. Elective hysterectomy: A clinicopathological review from abha catchment of Saudi Arabia. WAJM. 2005;24(1):24-9.

7. Pity IS, Jalal JA, Hassawi BA. Hysterectomy: A clinicopathologic study. Tikrit Med J. 2011;17(2):7-16.

8. Rahim G, Yudhvirgupta. Pattern of lesion in hysterectomy specimen: A prospective study. J K science. 2013;15(9):110-5.

9. Pradhanang V, Tuladhar H, Maskey S, Dali SM, Pradhan P. Review of Hysterectomies at NMCTH: A Retrospective Study. J Nep Health Res Coun. 2005;3(1).

10. Begum J, Talukder SI. A two year audit of complication of total abdominal hysterectomy at Dinajpur Medical Colleged hospital. Dinajpur Med Col J. 2008;1(1).

11. Zahan AA, Shahnawaz K. Non descent vaginal hysterectomy: a rational surgical approach. Bagladesh J Obstet Gynaecol. 2015;30(1):15-9.

12. Zaman S, Anjuman A. Begum. Hysterectomies at a rural medical college of Assam- A retrospective study. J Obstet Gynaecol Barpeta. 2015;1(2).

13. Abhulimen O, Isa IA. Omoregie Oyomwan Barry Hysterectomy in the Niger Delta of Nigeria: A Clinical Study of Indications and Outcome. Greener journal of medical science. 2012;2012(5):98.

Cite this article as: Mahilange A. Evaluation of hysterectomy in a tertiary care hospital of central India: a retroprospective study. Int J Reprod Contracept Obstet Gynecol 2021;10:3749-54. 